June 1993

EFFECTS OF MARINE MAMMALS ON COLUMBIA RIVER SALMON LISTED UNDER THE ENDANGERED SPECIES ACT ENDANGERED STOCKS OF SALMON IN THE SNAKE RIVER

Recovery Issues for Threatened and Endangered Snake River Salmon Technical Report 3 of 11

Technical Report 1993

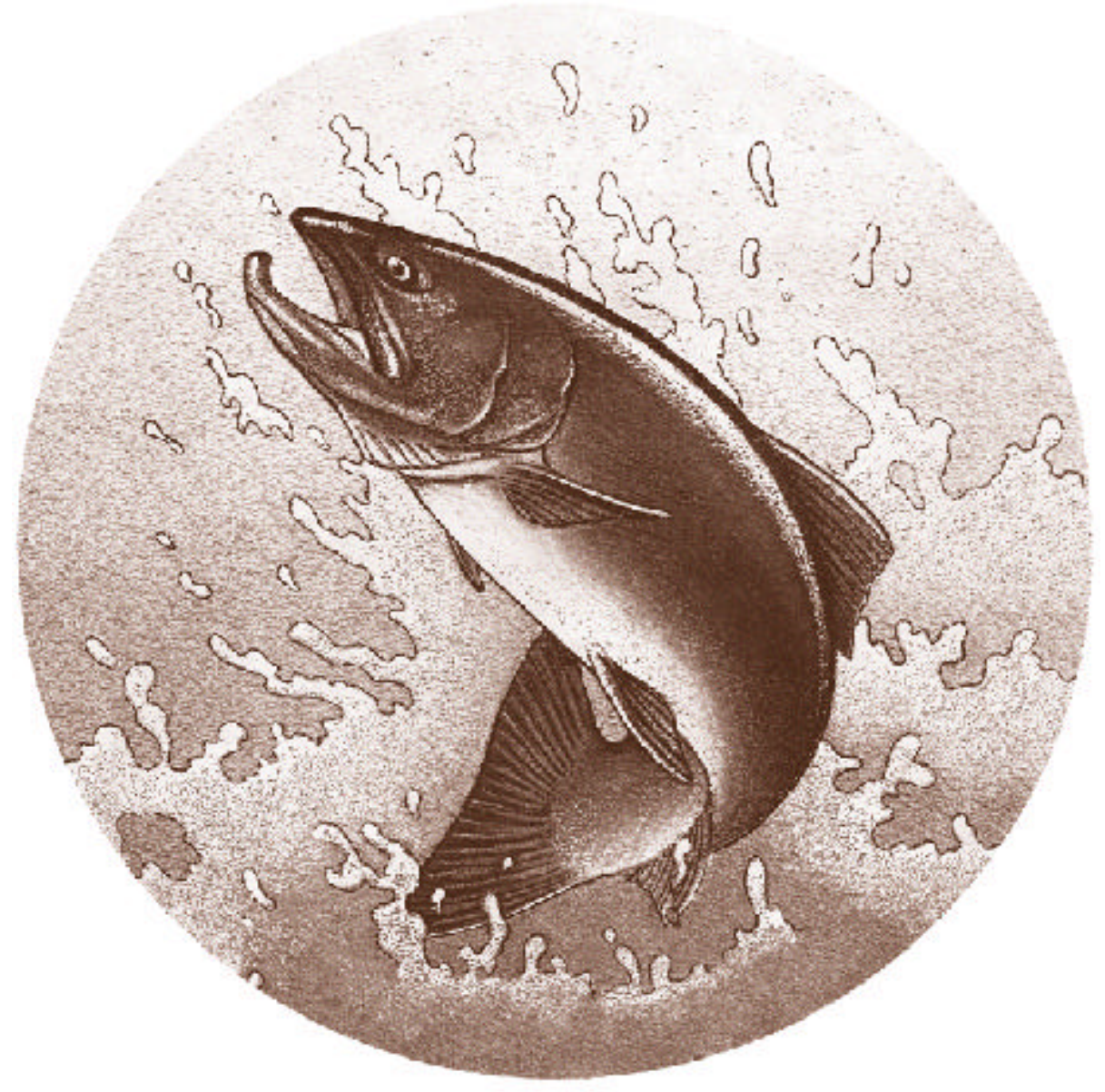

DOE/BP-99654-3 
This report was funded by the Bonneville Power Administration (BPA), U.S. Department of Energy, as part of BPA's program to protect, mitigate, and enhance fish and wildlife affected by the development and operation of hydroelectric facilities on the Columbia River and its tributaries. The views of this report are the author's and do $r$ necessarily represent the views of BPA.

This document should be cited as follows:

Park, D.L.; S.P. Cramer \& Associates, Inc., U.S. Department of Energy, Bonneville Power Administration, Division of Fish and Wildlife, Project No. 93-013, Contract No. DE-AM79-93BP99654, 18 electronic pages (BPA Report

DOE/BP-99654-3)

This report and other BPA Fish and Wildlife Publications are available on the Internet at:

\section{http://www.efw.bpa.gov/cgi-bin/efw/FW/publications.cgi}

For other information on electronic documents or other printed media, contact or write to:

Bonneville Power Administration

Environment, Fish and Wildlife Division

P.O. Box 3621

905 N.E. 11th Avenue

Portland, OR 97208-3621

Please include title, author, and DOE/BP number in the request. 
This report was funded by the Bonneville Power Administration (BPA), U.S. Department of Energy, as part of BPA's program to protect, mitigate, and enhance fish and wildlife affected by the development and operation of hydroelectric facilities on the Columbia River and its tributaries. The views in this report are the author's and do not necessarily represent the views of BPA.

For additional copies of this report, write to:

\section{Bonneville Power Administration \\ Public Information Center - CKPS-1 \\ P.O. Box 3621 \\ Portland, OR 97208}

Please include title, author, and DOE/BP number from the back cover in the request. 


\title{
EFFECTS OF MARINE MAMMALS ON COLUMBIA RIVER SALMON LISTED UNDER THE ENDANGERED SPECIES ACT \\ Recovery Issues for Threatened and Endangered Snake River Salmon Technical Report 3 of 11
}

\author{
Prepared by \\ D. L. Park 1 \\ under subcontract to \\ S.P. Cramer \& Associates, Inc. \\ Gresham, OR
}

Prepared for

U.S. Department of Energy

Bonneville Power Administration

Division of Fish and Wildlife

P.O. Box 3621

Portland, OR 97208-3621

Project No. 93-013

Contract No. DE-AM79-93BP99654

June 1993

1 Don Chapman Consultants, Inc., Boise, ID 


\section{TABLE OF CONTENTS}

EXECUTIVE SUMMARY i

1. INTRODUCTION

1.1 ACKNOWLEDGEMENTS

2. STATUS OF MARINE MAMMAL POPULATIONS

2

2.1. HARBOR SEALS

2.2. SEA LIONS

3. FOOD HABITS OF HARBOR SEALS 3

3.1. FEEDING RATES 3

3.2. ANALYSIS OF SEAL PREDATION ON SNAKE RIVER SPRING/SUMMER CHINOOK SALMON IN THE COLUMBIA RIVER ESTUARY 4

3.3. INCIDENCE OF BITE WOUNDING BY SEALS ON SPRING/SUMMER CHINOOK SALMON 5

3.4. PRESPAWNING MORTALITY DURING RIVER PASSAGE 6

4. SUMMARY OF MORTALITY DUE TO MARINE MAMMALS (HARBOR SEALS)

5. OTHER CONSIDERATIONS 8

6. MANAGEMENT CONSIDERATIONS 9

7. LITERATURE CITED 10 


\section{EXECUTIVE SUMMARY}

Most research on the Columbia and Snake Rivers in recent years has been directed to downstream migrant salmon (O ncorhynchus spp.) losses at dams .

Comparatively little attention has been given to adult losses. Recently (1991), an estimated 378,400 adult salmon and steelhead (0. mykiss) were unaccounted-for from Bonneville Dam to terminal areas upstream. It is now apparent that some of this loss was due to delayed mortality from wounding by marine mammals. This report reviews the recent literature to define predatory effects of marine mammals on Columbia River salmon.

Spring/summer chinook salmon (0. tshawytscha) have been observed by National Marine Fisheries Service biologists at Lower Granite Dam with bites, scars, and open flesh wounds caused by seals (sea lions) (Pinnepeds). During the last three years, the incidence of marks has ranged from 14 to $19.2 \%$ with about one-third of the marks consisting of open wounds. This gives cause to believe substantial losses are occurring from direct predation in the Columbia River estuary and further losses occur as fish die from wounds as they ascend the river.

The Marine Mammal Protection Act of 1972 has eliminated predatory losses of seals and sea lions except those caused by killer whales. With protection, seal and sea lion populations are now at or possibly exceed historic levels.

In British Columbia, harbor seals (Phoca vitulina) increased from about 9,000 animals during the mid-1970's to -about 90,000 in 1988. The Oregon herd (central Oregon coast to Grays Harbor) now stands at about 12,000. The Columbia River herd (part of the Oregon herd) is conservatively estimated to be 3,000 animals. The Columbia River herd has been growing at rates of 6 to $11 \%$ per year since 1978 .

California sea lions (Zalophus californianus) have also increased substantially with protection, but their population is more migratory than that of seals and they probably spend less time in the river. Mature bulls (at least some) are year-long residents on the coast and have been observed in the Columbia River up to Bonneville Dam. Though much larger than seals, they are far less abundant and likely of minor consequence as salmon predators in the river. Because of the importance of seals, seals are given extensive treatment in this report.

Harbor seals seem to prefer feeding on small fish such as herring (Clupeidae), anchovies (Engraulidae), and smelt (O smeridae). Small fish $<15 \mathrm{~cm}$ form about $62 \%$ of their diet and those fish over $15 \mathrm{~cm}$, including salmon, provide the balance. On a numerical basis, salmon provide $<1 \%$ of fish eaten. However, because most salmon eaten are in the large category, they may provide more than $10 \%$ of the total biomass consumed. In Oregon, the average seal weighs about $56 \mathrm{~kg}$ and requires about $2.8 \mathrm{~kg}$ of fish daily for weight maintenance. Estimates of salmon consumed by seals ranged from $20 \%$ of the Oregon commercial landing in 1980 (Harvey 1988) to 59\% of the catch in 1991 (Kaczynski and Palmisano 1992).

Seals are nomadic and most of the Columbia River herd resides outside the Columbia much of the year. It has been postulated that seals follow the smelt 
(eulachon) into the river in January. I hypothesize that during January-February the abundant smelt provide much of the fish needed by seals. However, the smelt run is of short duration, and as spring chinook become available (some runs enter the river in February) seals turn to salmon as the smelt run passes upriver.

Using food habit and consumption rate data of others, I estimate that 3,000 seals would take about 22,500 spring/summer chinook salmon during a 100-day period from late February through May. Fish consumed were from various stream sources, so perhaps $20 \%$ or about 4,500 fish (conservative estimate) were Snake River spring chinook (I separate spring-run from summer-run fish because no estimate of upriver losses for summers could be established).

Bite marking (including scars and open wounds) observed at Lower Granite Dam provides solid data that Snake River salmon are being lost to seal predation and delayed mortality. A marine mammal expert viewed photographs of injured salmon and identified the bites as those made by harbor seals. Since the photograph sample was obviously small, it is possible or even likely that some marks were made by sea lions.: For several reasons, I attribute them to seals.

Based on data from Lower Granite Dam, predatory attacks were more severe on spring chinook than summer-run fish. In 1991, 20.9\% of the spring chinook were scarred compared with $9.4 \%$ of the summer-run fish. In 1992, $17.4 \%$ and $7.6 \%$ were marked from the respective spring and summer runs. This suggests that some stocks of wild spring chinook were fished heavily by seals.

Bite marking observed leads- to suspicion that delayed mortality after predation (interdam loss) was substantial. I estimate that interdam losses due to seal bites during 1990 to 1992 were about 3,600; 1,500; and 2,900 in respective years. Additional prespawning mortalities between Lower Granite Dam and the spawning areas were 2,$900 ; 1,100$; and 2,300 during the same years. In 1992 , total mortality was 9,700 or about 3,900 wild spring run adults (includes estimates of direct predation, interdam loss, prespawning loss, and assumes that $40 \%$ of the run were wild fish).

There may be a competitive interaction between marine mammals, juvenile hatchery fish, and young wild fish. Herring and other small fish are important food sources of all three groups of animals. In years when salmon survive poorly in the ocean, lack of prey species for salmon may be made worse by grazing by marine mammals. Also, abundant hatchery fish have been and continue to compete with the wild fish for a finite food supply. I speculate that numerous hatchery fish released each year into the Columbia River may provide an attraction for holding marine mammals in the estuary while they feed on juveniles and adults as they pass through at the same time.

Historic high populations of marine mammals must be addressed. A holistic approach to management is a basic requirement. One approach is to amend the Marine Mammal Protection Act of 1972 which is in the process of re-authorization (1993). Action is required now to take into account threatened Snake River salmon. 


\section{EFFECTS OF MARINE MAMMALS ON COLUMBIA RIVER SALM O N LISTED UNDER THE ENDANGERED SPECIES ACT}

\section{INTRODUCTION}

Most research has centered on safe passage of juvenile salmon during their downstream migration. Of equal importance is the safe upstream passage of adults. Harbor seals (Phoca vitulina) and California sea lions (Zalophus californianus) now appear as an important concern to safe passage in the lower Columbia River (Chapman et al. 1991 and Kaczynski and Palmisano 1992).

The National Marine Fisheries Service (NMFS) reports that seal and California sea lion populations are increasing and that predation is now occurring in all Northwest fisheries (NMFS 1988). Marine mammals now regularly harass commercial fisherman, taking fish from purse seines and gillnets (Kaczynski and Palmisano 1992). Additional damage occurs by biting and tearing fish in gillnets, which reduces their values in the marketplace. In the Klamath River, seal predation on chinook trapped in gillnets was an estimated at $13.2 \%$ (CH2M Hill 1985) and in the Columbia River damage was estimated to represent $12.3 \%$ of the gillnet catch in 1981 (Reach 1982).

Of special concern is the consistent (last three years) presence of wounds and bite marks on spring/summer chinook salmon at Lower Granite Dam (Harmon et al. manuscript in preparation). The bites were originally identified as those made by harbor seals, but some may have been caused by sea lions. Harbor seals and sea lions were formerly uncommon. In recent years they have been regularly observed feeding as far upstream as Bonneville Dam (NMFS 1992), where adult fish tend to congregate as they begin to ascend the fishways.

It is important to separate, if possible, the difference between dam-caused mortality and predator-caused mortality during passage upriver. For example, Kaczynski and Palmisano (1992) calculated that 378,400 adults (all species) were lost during Columbia River dam passage. This' represents a sizeable loss, and if it is all due to passage facilities at dams is certainly worth fixing. Some of the loss was due to mortality along the migration corridor because of previous wounding by marine mammals. In this report, I present an analysis of predation in the Columbia River estuary and interdam loss due to wounding by marine mammals.

\subsection{ACKNOWLEDGEMENTS}

Regional ratepayers supported this report through the Bonneville Power Administration. I thank Ms. Deborah Watkins, Project Manager, for her guidance and direction. 


\section{STATUS OF MARINE MAMMALPOPULATIONS}

Historically, predation on seals by killer whales and hunting of seals by native North Americans for food and clothing kept seal populations in check (Chapman et al. 199 1). Later, seals and sea lions were killed by commercial fishermen who viewed these mammals as fierce competitors for declining stocks of salmon. Since 1972, marine mammals have been protected from harvest and harassment by the Marine Mammal Protection Act in the U.S. and by similar legislation in Canada (Olesiuk et al. 1990). Declining predator populations (killer whales) and cessation of hunting and harassment has likely allowed seal and sea lion populations. to rebound dramatically.

\subsection{HARBOR SEALS}

In British Columbia seal herds increased from an estimated 9,000-10,500 prior to protection to $80,600-90,140$ by 1988 (Olesiuk et al. 1990). Olesiuk believes that the herd is now at, or actually exceeds carrying capacity in the northern range.

Farther south, the Columbia River herd count on April 8, 1978 was 1,509.

During the early 1980s the herd increased at about $11 \%$ per year (Beach 1985). By 1990 the herd was still increasing but had slowed to about $6 \%$ per year (J. Harvey personal communication). Over all, the Oregon herd (central Oregon coast to Grays Harbor) increased from about 5,000 in 1980 to 10,000 by 1990 (Chapman et al. 1991; Kaczynski and Palmisano 1992). The most recent published estimate of herd size is now about three years old. If we assume the herd is still increasing at the last estimate of $6 \%$ per year, the herd now stands at about 12,000 animals.

The number of seals in the Columbia River herd (1990), reported by Chapman et al. (1991) as 2,100 animals, appears to be an underestimate. Using Jeffries' (1983) most conservative estimate of 1,500 seals, I calculate that if the herd grew at a rate of $11 \%$ per year 1979 through 1985 and then at 6\% through 1990, the herd would stand at 4,192 post-pupping population in 1990 . If the herd increased at only $6 \%$ each year since 1978, the 1993 population would be about 3,600. Furthermore, if the total Oregon herd doubled in size from 1980 to 1990, logic dictates that the Columbia River herd would have doubled in a 12-year span. In analyses presented later in this report I use a base of 3,000 animals a very conservative figure given the above estimates ${ }^{1}$.

\footnotetext{
1. All published data on Columbia River herd size reflect numbers observed by aerial counts. Counts are made during pupping season (May) when 'harbor seals are actually beginning to move out of the river. Also counts are not adjusted to reflect those seals that are underwater at the instant of counting. Counts should probably be adjusted upward by a factor of 1.5 or 2.0 (S. Jeffries, Washington Department of Wildlife, personal communication). Realistically, the number of harbor seals in the Columbia River at their peak seasonal abundance could be 4,500 to 6,000 animals.
} 


\subsection{SEA LIONS}

California sea lions were uncommon along the O regon coast during the 1960s (Kaczynski and Palmisano 1992). In 1980 an estimated 200 animals foraged along the Oregon coast (Beach et al. 1985). By 1990 the population had reached 6,000 animals in the fall northward migration (Bigg 1985). In mid-March the herd migrates south again. It is this migration that may be important in attributing losses of Snake River chinook salmon to sea lions because the spring/summer run enters the Columbia River estuary coincidentally with this migration. Obviously, most sea lions do not enter the river or a more significant population would have been reported there. It' appears that mature bulls may be among predators observed as far upstream as Bonneville Dam and those which are of the most serious concern here (Beach et al. 1982). Numerically, sea lions are far less important than seals as predators in the Columbia River estuary, though individually they consume two to three times as much salmon as do seals (Kaczynski and Palmisano 1992).

In 1991 there was a resident population of 200 to 400 sea Northern sea lions in Oregon waters (Kaczynski and Palmisano 1992). The population may expand to about 3,000 animals during the early summer breeding season. This species is larger than the California sea lion and adults require about twice as much food as California relatives, and about five to six times the food consumed by harbor seals.

\section{FOOD HABITS OF HARBOR SEALS}

Seals are opportunistic feeders. Their body shape, head size, and small mouth indicate they may do well eating small fish. Experts agree that small prey species such as herring (Clupeidae), anchovies (Engraulidae), and smelt (Osmeridae) form the bulk of their diet (Harvey 1988). Harvey found that 62\% of their forage items fell in the 8-15 $\mathrm{cm}$ size class. Fish over $15 \mathrm{~cm}$, including salmon, provide the balance of their diet (Ibid.).

\subsection{FEEDING RATES}

To understand the importance of seal predation on salmon, we must know the size of the animal, how long it lives, how much it requires for body maintenance and growth, and have a reasonable estimate of what seals consume.

In Oregon, seal average weight was 55.7 kilograms among a sample of 217 animals (Harvey 1988). In Washington (Grays Harbor), the average was near 50 kilograms, but sample size including pups was small (pup data were not used for weight analysis).

The average age of seals was three years in the Grays Harbor sample. The oldest seal sampled was a 19-year-old female ((Jeffries and Johnson 1983).

Food consumption rates for seals vary. Season, breeding, lactation, and size of , animal are among factors influencing food consumption. For example, fast-growing 
immature animals probably require more food than non-breeding old animals, even though the mature animals weigh more (Chapman et al. 1991). Harvey (1988) found that among captive animals, weight could be maintained at a feeding rate of $5 \%$ of body weight. Seals gained weight if feed was increased to $10 \%$ of body weight. The daily maintenance diet required for the average seal (55.7 kilograms) would be 2.785 kilograms of fish (Harvey 1988).

When salmon are available, seals consume them in quantity. In fact, Harvey (1988) estimated that seals consumed 604.5 metric tons of salmon along the Oregon coast in 1980. Most of these were in the "feeder" size class. Salmon represented 10.8\% of total biomass consumed by seals. Numerically, c $1 \%$ of diet is composed of salmon, but because the salmon are usually much larger than other prey species, total biomass may be $10 \%$, or more. Harvey's data are compelling for two reasons. First, his study was far more comprehensive than others, indicating that timing of stomach and scat collections is very important if seasonal variation in diet occurs. Second, he found salmon otoliths in feces only in the Columbia and Rogue River estuaries, indicating predation on salmon may be important only in certain locales.

In 1980, 12,448.7 metric tons of fish were landed in Oregon (Harvey 1988). Among species consumed by seals there were 3,067.9 metric tons of which 2,000 metric tons were salmon. An estimated 600 metric tons (equivalent to $20 \%$ of the commercial landing) of salmon were consumed by seals--in a sense, severe competition with man. Ten years later, Kaczynski and Palmisano (1992) estimated that a herd of 10,000 seals would have consumed 205,610 salmon, or 58\% of the Oregon ocean commercial landing.

\subsection{ANALYSIS OF SEAL PREDATION ON SNAKE RIVER SPRING/SUMMER CHINOOK SALMON IN THE COLUMBIA RIVER ESTUARY}

Earlier, I suggested that there are now an estimated 3,000 (conservative estimate) harbor seals in the Columbia River population. The herd is a nomadic one--migrating in and out of the lower river. It has also been suggested that seals enter the river in January as they follow runs of eulachon (Chapman et al. 1991). By late February, the eulachon have passed upriver and first arrivals of the spring/summer chinook have entered the estuary. I postulate that lacking sufficient prey of a preferred nature (e. g., eulachon), seals turn to salmon, which are at the time becoming more numerous. There is strong evidence that seals are preying heavily on Snake River spring/summer chinook salmon throughout the run. This will be addressed in more detail later.

If Harvey's salmon consumption data, (Harvey 1988) are applied to the 3,000 seals now estimated to be present in the Columbia River over about 100 days when Snake River salmon are there, an estimate of Snake River chinook salmon consumed can be made. Total consumption could amount to 22,558 salmon (3,000 seals x $2.785 \mathrm{~kg}$ fish in maintenance diet x 100 days x 0.108 Harvey's percent estimate of salmon in diet x $4 \mathrm{~kg}$ average weight of salmon) $=22,558$. Most of the salmon migrating through the estuary are not of Snake River origin. A rough estimate might be $20 \%$ are Snake River salmon or about 4,500 fish.

An accurate assessment of seal consumption in the estuary is impossible. Yet my 
estimate is certainly plausible. Most, if not all my parameters are conservative. I use maintenance diet in place of a growth diet; a conservative weight of salmon (nearly all Snake River chinook exceed four kilograms except jacks); and percent of salmon in diet in this instance is likely an underestimate. Logically, in a seal's view, when salmon are scarce they eat other more abundant fish species. In this instance salmon are abundant, and I suggest they may form a much higher rather than lower percentage of daily diet requirements.

\subsection{INCIDENCE OF BITE WOUNDING BY SEALS ON SPRING/SUMMER CHINOOK SALMON}

During recent years, seal bites (marks, scarring, and wounding) have been identified on adult spring/summer chinook by National Marine Fisheries Service (NMFS) biologists at Lower Granite Dam (Harmon et al. manuscript in preparation). Detailed accounting of bites was recorded at the dam from 1990 to 1992 (Table 1). In 1990, fish with marks were photographed and marks were identified by Dr. Robert Delong, a National Marine Fisheries Service marine mammals specialist. In addition, some bite marks were measured that suggested that seals caused most of the damage (J. Harmon, NMFS, personal communication). Since damage occurred with such a variety of wounds, marking on some fish may have been caused by sea lions as well. Biologists have inspected adult fish at one or more of the Snake River dams since 1970. In most years they noted wounds inflicted by seals, but severe incidence before 1990 only in 1973_.

Table 1. Percentage of adult spring/summer chinook salmon observed with seal bite marks at Lower Granite Dam during years 1990-1991.

Year $\quad \underline{\text { Incidence (\%) }}$ Open wounds (\%) Sample size

$\begin{array}{llll}1990 & 19.2 & 36.0 & 1700+\end{array}$

$\begin{array}{llll}1991 & 14.0 & 47.0 & 1325\end{array}$

$\begin{array}{llll}1992 & 14.7 & 36.4 & 3255\end{array}$


(Chapman et al. 1991). Prior to 1990 bite marking existed, but now with three consecutive years of data, the problem is alarming 2 .

Obviously, wounding occurs during unsuccessful seal attacks. It has been estimated that seals attack 100 times before each salmon is caught (Chapman et al. 1991). The frequency of near-misses (wounding) in unsuccessful seal attacks is unknown. We do know that over the last three years from 1 in 5 to 1 in 7 listed Snake River spring/summer chinook have been wounded and suggests that every fish in the migration could have experienced a predacious attack in the estuary. There is evidence that bite marking is much worse during the spring segment of the run than during the summer run. During 1991, bite marks were evident on $20.9 \%$ of the spring fish and $9.4 \%$ of the summer fish. In 1992, the numbers were $17.4 \%$ and $7.6 \%$, respectively. These data suggest that seals were either beginning to leave the estuary, or that more abundant prey species were allowing the less abundant summer run fish to escape. The data also suggest that fish from some streams where spring run fish spawn are fished very heavily by seals.

\subsection{PRESPAWNING MORTALITYDURING RIVER PASSAGE}

During the spring/summer chinook salmon runs 1990 to 1992 , there is no documented loss during river passage that can be directly attributed to seals (marine mammals). However, since 14.0 to $19.2 \%$ (higher for springs only) of the fish at Lower Granite Dam showed evidence of bites it is implied that delayed mortality due to wounding was substantial. An analysis of delayed mortality during river passage presented by Chapman et al. (1991) is useful here:

To estimate mortality (delayed) of Snake River spring chinook salmon due to seals, we compared dam counts at McNary Dam with counts taken togetherfrom Lower Granite and Priest Rapids Dams and the Yakima River [(Table F7) (Table 2)] for 1981-1990. We suspect Snake River fish dropped out also between Bonneville and McNary Dams, but counts are confusing and of little value because of low er river tributary turnoffs, especially in the Bonneville pool. Therefore, loss in this stretch is discounted. The discrepancy between McNary and the upper count stations is considered unaccountable loss. Since interdam loss occurs each year (and probably at each dam), we averaged the loss rate (excepting 1983 and 1990) to determine an expected annual loss rate. (High unaccountable loss in 1983 cannot be explained, but may be attributable in part to seals.) Average annual loss was $4,060(9.4 \%$ of the $M c N$ Nary Dam count). Subtracting 4,060 from 10,915 (total observed unaccountable loss in 1990) leaves an additional. loss of 6,855 upriver fish

2. During the first part of the spring run in 1993, bite incidence on chinook salmon was $30 \%$ (J. Harmon, NMFS, personal communication). 
which we can attribute to seal bites. Each counting area was assessed its share (based on observed run size) of the estimated loss: Snake River 3,640; mid-Columbia River 2,587; and Yakima River 628.

Table 2. (Table $F 7$ Chapman et al. 1991). Loss rate of adult spring chinook salmon from McNary Dam to upstream observation points (Priest Rapids, Lower G ranite and Yakima River from 1981 to 1990. (1991 and 1992 data have been added.)

\begin{tabular}{llllc}
\hline Year & McNary Dam & $\begin{array}{l}\text { PRD }+L W G+ \\
\text { Yakima River }\end{array}$ & $\begin{array}{l}\text { Loss } \\
\text { Rate(\%) }\end{array}$ & $\begin{array}{c}\text { Unaccountable } \\
\text { Loss }\end{array}$ \\
1992 & 50,504 & 43,063 & 14.7 & 7,441 \\
1991 & 22,631 & 18,251 & 19.4 & 4,380 \\
1990 & 43,178 & 32,263 & 25.3 & 10,915 \\
1989 & 32,502 & 28,723 & 11.6 & 3,779 \\
1988 & 48,885 & 46,305 & 3.3 & 2,580 \\
1987 & 58,787 & 51,000 & 13.3 & 7,787 \\
1986 & 73,244 & 62,141 & 15.3 & 11,103 \\
1985 & 55,945 & 53,041 & 5.2 & 2,904 \\
1984 & 23,718 & 20,855 & 12.1 & 2,863 \\
1983 & 29,874 & 21,012 & 29.7 & 8,862 \\
1982 & 24,920 & 22,533 & 9.6 & 2,387 \\
1981 & 29,533 & 28,703 & 2.9 & 830 \\
& & & & \\
\hline
\end{tabular}

Using the above analysis for 1991 and 1992, I estimate the interdam loss attributed to seals as 1,471 and 2,900 adults respectively.

From the NMFS field data and from the USACE dam count data, I estimate that among the spring run chinook at Lower Granite Dam in 1990 to 1992; 4200, 1600, and 3300 fish in respective years had marks or wounds by seals. The expected normal mortality between Lower Granite Dam and the spawning grounds/hatchery was estimated to be 35\% (Chapman et al. 1991) and that mortality among wounded fish would be about double normal mortality. The higher mortality value for marked and wounded fish is justified by the fact that about one-third of the marked fish had wounds classified as open flesh, a fact that offers little hope of survival to spawning for those severely wounded fish. The estimated mortality from the dam to spawning grounds is: 1990--2,940 fish; 1991--1, 120 fish; and 1992--2,310 fish.

\section{SUMMARY OF MORTALITYDUE TO MARINE MAMMALS (HARBOR SEALS)}

A summary of mortality of spring run chinook salmon due to predation, interdam 
loss, and prespawning loss because of seals is provided in Table 3 . I believe the summary data in Chapman et al.(1991) was in error in by underestimating the number of seals.

Table 3. Summary of estimated mortality of Snake River spring chinook salmon due to harbor seals during. 1990 to 1992.

\begin{tabular}{|c|c|c|c|}
\hline $\begin{array}{l}\text { Mortality } \\
\text { reach }\end{array}$ & $\begin{array}{l}\text { Number killed } \\
\quad 1990 \\
\end{array}$ & $\begin{array}{l}\text { Number killed } \\
1991 \\
\end{array}$ & $\begin{array}{l}\text { Number killed } \\
1992\end{array}$ \\
\hline Col. R. estuary & 3,000 & 1,500 & 4,500 \\
\hline $\begin{array}{l}\text { McNary to Lower } \\
\text { Granite }\end{array}$ & 3,640 & 1,471 & 2,900 \\
\hline $\begin{array}{l}\text { Lower Granite to } \\
\text { spawning grounds }\end{array}$ & 1,500 & 1,120 & 2,310 \\
\hline Totals: & 8,140 & 4,091 & 9,710 \\
\hline
\end{tabular}

However, I have not adjusted upward the estuary predation mortality. In general, all of my estimates are conservative with the possible exception of the interdam mortality. This segment of mortality is extremely difficult to define; however my estimate appears plausible since it does not account for any mortality in the Bonneville Dam to McNary Dam reach. In conclusion, it appears that about 20\% to 30\% of the spring run (run size at the mouth of the estuary) have been harvested by seals in each of the last three years.

Up to now, I have not addressed the issue of effect of marine mammal predation on wild fish specifically. Recent estimates of wild fish in the spring run returning to the Snake River vary from about 25 to 60\% (Raymond 1988 and Williams et al. 1990). It is probably safe to say that the 1990 to 1992 runs were composed of about $40 \%$ wild fish. Based on this percentage, total loss of wild fish would be approximately 3200,1600 , and 3900 for each year 1990 to 1992 respectively.

\section{OTHER CONSIDERATIONS}

Excessive numbers of marine mammals may pose a serious threat as competitors with immature wild Snake River salmon (Kaczynski and Palmisano 1992). Both feed on herring and other "bait" species. It is possible that in recent years when ocean survival 
for salmon was poor, mortality was due in part to a low supply of forage species created by overgrazing by marine mammals.

Huge numbers of hatchery fish could present themselves as a forage attraction that actually holds seals in the estuary throughout the spring. Over 200 million hatchery fish are released in Northwest waters each year (Kaczynski and Palmisano 1992) with most of the releases made in the Columbia River system.

There is an overabundance of marine mammals and an over- abundance of hatchery fish all competing with a remnant population of wild fish for a finite supply of prey (in the ocean, salmon and marine mammals eat the same prey species).

Confounding this interaction, both hatchery and wild salmon are consumed by marine mammals.

\section{MANAGEMENT CONSIDERATIONS}

It appears that marine mammal experts are in agreement that pinnepeds are near or exceed historic population levels. Wild salmon, on the other hand, are far below historic population levels in all Northwest waters. Marine mammals are more adaptive than salmon. Their numbers continue to increase as those of salmon decline. The Washington Department of Fisheries (WDF) has established the problem of marine mammals as one of six planning uncertainties: "Consumption of salmon by Marine Mammals must now be considered in planning. These are fish which otherwise may have been caught by commercial and recreational fishers" (Anon. 1992). They could have added to their statement "or in the case of wild salmon, escaped to underseeded spawning grounds. " There is no question that pinnepeds are taking a disproportionate number of listed Snake River salmon. What, then, is the appropriate management action?

A holistic approach to management is essential. I believe that fisheries biologists and marine management biologists are not communicating. During interviews with marine mammal experts, it was my perception that they were withholding most recent information on marine mammal abundance and predatory effects on salmon. They may not have the hard data I. was seeking. If so, we desperately need more data so reasoned decisions on protection can be made.

It is our responsibility as fisheries biologists/managers to meet with marine mammal biologists/managers to develop a plan for co-management of the respective species. Bureaucracies, empires, and 'institutions must be put aside. In Oregon, marine mammals now take as many salmon as does man (Kaczynski and Palmisano 1992). It seems that marine mammals are managing men and salmon. That was not the intent of the Marine Mammal Protection Act of 1972. The Marine Mammal Protection Act will be re-authorized in 1993 (personal communication, T. Wright, Northwest Indian Fisheries Commission, Olympia, WA). Threatened and endangered salmon must have representation in the re-authorization process. 


\section{LITERATURE CITED}

Anonymous. 1992. Salmon 2000: Technical Report. Washington Department of Fisheries, Olympia, WA. 339 p.

Beach, R., and others. 1935. Marine mammals and their interaction with fisheries of the Columbia River and adjacent waters, 1980-1982. Third annual report. Washington Department of Wildlife, Wildlife Management Division, Olympia, WA.

Bigg, M. 1985. Status of Stellar sea lion (Eumetopias jubatus) and California sea lion (Zalophus californianus) from British Columbia during 1981-1982, with some records from Washington and Southeast Alaska. Canadian Data Report of Fisheries and Aquatic Sciences. 460.

Chapman, D., A. Giorgi, M. Hill, A. Maule, S. McCutcheon, D. Park, W. Platts, K. Pratt, J. Seeb, L. Seeb, and F. Utter. 1991. Status of Snake River chinook salmon. Pacific Northwest Utilities Conference Committee. Portland, OR.

CH2M Hill. 1985. Klamath River Basin fisheries resource plan. USDI, BIA, Redding, CA.

Harmon, J. R., K. L. Thomas, D. W. McIntyre, and Neil N. Paasch. Manuscript in preparation: Incidence of marine mammal teeth and claw abrasions on adult anadromous salmonids returning to the Snake River. NOAA, NWFC, National Marine Fisheries Service, 2725 Montlake Blvd. E., Seattle, WA.

Harvey, J. T. 1988. Population dynamics, annual food consumption, movements, and dive behavior of harbor seals (Phoca vitulina richardsi) in Oregon. PhD thesis. Oregon State University. 120 p.

Jeffries, S., and M. Johnson. 1983. Population status and condition of harbor seals (Phoca vitulina richardsi) in waters of state of Washington--1975-1980. Final report to the Marine Mammals Commission. 70 p.

Kaczynski, V. W., and J. F. Palmisano. 1992. A review of management and environment factors responsible for the decline and lack of recovery of Oregon's wild anadromous salmonids. Oregon Forest Industries Council. Salem, OR. 292 p.

National Marine Fisheries Service. 1991. Factors for decline: A supplement to the notice of determination for Snake River fall chinook salmon under the Endangered Species Act. National Marine Fisheries Service, Portland, OR. 55 p.

National Marine Fisheries Service. 1988. Marine Mammal Protection Act of 1972. Annual report 1987/88. Washington, D. C. U. S. Department of Commerce. 
Olesuik, P. F., M. A. Bigg, and G. M. Ellis. 1990. Recent trends in abundance of harbor seals (Phoca vitulina) in British Columbia. Canadian Journal of Fisheries and Aquatic Sciences. 47(5):992-1003.

Raymond, H. L. 1988. Effects of dams and impoundments on migrations of juvenile chinook salmon and steelhead in the Columbia River Basin. North American Journal of Fisheries Management. 8(1): 1-23.

Williams, J., D. Park, and G. Matthews. 1990. Snake River spring chinook salmon stocks--a case for wild fish. Idaho Chapter American Fisheries Society annual meeting. Boise, ID. 